Marcin Grad

Uniwersytet Warszawski

ID ORCID ID: 0000-0003-2800-2721
OBLICZA WOJNY

TOM $3 \cdot$ MIASTO I WOJNA

ŁÓDŹ2021 • ISBN 978-83-8220-556-5 • s. 311-339

https://doi.org/10.18778/8220-556-5.17

\title{
WOJENNA HISTORIA WARSZAWY OCZAMI TRZECH WĘGIERSKICH DZIENNIKARZY I PISARZY
}

\begin{abstract}
Streszczenie. Artykuł jest omówieniem wojennych dziejów Warszawy, przedstawionych na kartach trzech węgierskich reportaży: A Visztula sellője. Lengyelországi útinapló (Wiślana syrenka. Dziennik podróży po Polsce) Györgya Somlyó, A Kárpátoktól a Balti-tengerig (Od Karpat do Battyku) Tibora Pethő oraz Varsói hajnal (Warszawski świt) Pétera Ruffyego. Książki te są owocem wizyt w Polsce wymienionych dziennikarzy i pisarzy z Węgier. Somlyó, Pethő i Ruffy odwiedzili Polskę (w tym Warszawę) w latach pięćdziesiątych, kiedy to pamięć o kataklizmie II wojny światowej była jeszcze bardzo żywa, a w stolicy widoczne były ślady działań wojennych. W relacjach węgierskich autorów dotyczących losów Warszawy w latach II wojny światowej ważne miejsce zajmuje przedstawienie dwóch powstań - powstania w getcie warszawskim z 1943 roku i powstania warszawskiego z 1944 roku (dla ścisłości należy zauważyć, że György Somlyó o tym ostatnim nie pisze prawie nic, co może być motywowane względami politycznymi i ideologicznymi). Przedstawiony na kartach A Visztula sellője, A Kárpátoktól a Balti-tengerig oraz Varsói hajnal obraz wojennych dziejów Warszawy wpisuje się całkowicie w powojenną polską narrację polityczną i historyczną, jest też w pewnej części (np. odnośnie do powstania warszawskiego) nacechowany propagandowo. Mimo tych „mankamentów” omawiane reportaże z pewnością przyczyniały się w swoim czasie do poszerzenia wiedzy węgierskich czytelników na temat wydarzeń II wojny światowej w Warszawie i ogólnie w Polsce, a także odnośnie powojennej odbudowy kraju, którą jednak z powodu ograniczeń dotyczących objętości tekstu nie zajmuję się w tym artykule.
\end{abstract}

Słowa kluczowe: Warszawa, II wojna światowa, reportaż, Węgrzy, powstanie w getcie warszawskim, powstanie warszawskie

\section{Wprowadzenie}

Jednym ze skutków II wojny światowej były olbrzymie straty osobowe i materialne poniesione przez państwo polskie. Pamięć o tragicznych wydarzeniach II wojny światowej była bardzo żywa przez wiele lat; podobnie ślady zniszczeń 
wojennych były obecne w pejzażu wielu polskich miast, a nawet stanowiły wyraźny jego element, jeszcze długo po zakończeniu walk.

Powojenna Polska była przedmiotem zainteresowania węgierskiej inteligencji - w tym pisarzy i dziennikarzy. W latach pięćdziesiątych Polskę odwiedzili między innymi dziennikarz Tibor Pethő, dziennikarz i pisarz Péter Ruffy oraz poeta, pisarz, eseista i tłumacz literatury pięknej György Somlyó; owocem ich podróży są trzy książki - reportaże, opisy podróży po naszym kraju: A Visztula sellöje. Lengyelországi útinapló (Wiślana syrenka. Dziennik podróży po Polsce; wyd. 1954, autor: György Somlyó), A Kárpátoktól a Balti-tengerig (Od Karpat do Battyku; wyd. 1956, autor: Tibor Pethö) oraz Varsói hajnal (Warszawski świt; wyd. 1961, autor: Péter Ruffy) ${ }^{1}$. Warto dodać, że są to trzy pierwsze wydane po wojnie węgierskie książki-reportaże dotyczące Polski.

Celem artykułu jest przedstawienie i omówienie tego, w jaki sposób Tibor Pethő, Péter Ruffy i György Somlyó przekazywali węgierskim czytelnikom w swoich reportażach informacje o wydarzeniach II wojny światowej w Polsce; skupiam się przy tym na tworzonym przez węgierskich autorów „,wojennym” obrazie Warszawy². Stolica Polski odegrała bowiem ważną rolę w historii II wojny światowej - była miejscem nasilonego hitlerowskiego terroru, sceną dwóch powstań (ich obrazowi poświęcam sporo uwagi), została w znacznym stopniu zniszczona przez Niemców, wręcz uległa zagładzie, stając się tym samym symbolem kataklizmu II wojny światowej. Dodatkowo po 1945 r. Warszawa stała się wielkim placem (od)budowy - co było skrzętnie wykorzystywane przez ówczesną propagandę komunistycznych władz Polski, było także najważniejszym obszarem tematycznym reportaży wspomnianych wyżej Węgrów ${ }^{3}$. Ważnym i ciekawym zagadnieniem, jakie częściowo poruszam w artykule, jest wiarygodność przedstawianego w wymienionych reportażach obrazu Warszawy, wpływ

1 Żadna z tych trzech książek nie została przetłumaczona na język polski. Wykorzystane w tym artykule przekłady fragmentów reportaży są mojego autorstwa.

${ }^{2}$ Jeśli chodzi o polskojęzyczne publikacje, w 2019 r. obrazowi Warszawy nakreślonemu w trzech wymienionych reportażach poświęciłem osobny artykuł (dane bibliograficzne podaję w jednym z kolejnych przypisów oraz bibliografii). W tej publikacji na nowo podejmuję i znacznie rozbudowuję poruszony częściowo w artykule z 2019 r. wątek wojennych dziejów Warszawy, opisywanych przez wymienionych węgierskich pisarzy i dziennikarzy.

${ }^{3}$ Z powodu ograniczeń dotyczących objętości artykułu zrezygnowałem z choćby krótkiego omówienia także tego zagadnienia. 
ówczesnych uwarunkowań politycznych i społecznych, w tym komunistycznej propagandy, na spostrzeżenia i relacje Tibora Pethő, Pétera Ruffyego oraz Györgya Somlyó.

\section{Pobyt w Polsce Györgya Somlyó, Tibora Pethő i Pétera Ruffyego}

Z tekstu reportaży wynika, że wizyty w Polsce wymienionych pisarzy i dziennikarzy miały charakter służbowy (podróże służbowe zresztą to jeden z niewielu faktycznie dostępnych sposobów podróżowania w latach pięćdziesiątych). Węgierscy autorzy na kartach tychże reportaży podają, kiedy byli w naszym kraju. I tak, wizyta Györgya Somlyó w Polsce trwała od 4 kwietnia do 3 maja 1954 r. ${ }^{4}$ Tibor Pethő przebywał nad Wisłą wiosną 1955 roku, od końca kwietnia do mniej więcej połowy maja. Jak wynika z tekstu reportażu, Pethő wyjechał z Polski krótko po rozpoczęciu konferencji ośmiu europejskich państw socjalistycznych (jej uwieńczeniem było uroczyste podpisanie Układu Warszawskiego w dniu 14 maja) $)^{5}$. Warto dodać, że z innej części reportażu jasno wynika, że Pethő był w Polsce także w 1948 r. - uczestniczył w Światowym Kongresie Intelektualistów w Obronie Pokoju, zorganizowanym we Wrocławiu ${ }^{6}$. Trzeci z autorów, Péter Ruffy - jak sam pisze w końcowej części swojej książki - między 1945 a 1960 r. był w naszym kraju czterokrotnie ${ }^{7}$. Należy zaznaczyć, że opisuje on Polskę przede wszystkim przełomu lat pięćdziesiątych i sześćdziesiątych, z tej perspektywy podsumowuje przemiany, jakie dokonały się w naszym kraju od 1945 r. $^{8}$

${ }^{4}$ Gy. SomLYó, A Visztula sellóje. Lengyelországi útinapló, Budapest 1954, s. 81.

5 T. PетHÖ, A Kárpátoktól a Balti-tengerig, Budapest 1956, s. 239-246.

${ }^{6}$ Ibidem, s. 12.

7 P. RufFy, Varsói hajnal, Budapest 1961, s. 191.

${ }^{8}$ M. Grad, Trzech Wegrów nad Wistą. Warszawa oczami Tibora Pethö, Pétera Ruffy'ego oraz Györgya Somlyó, „Almanach Warszawy” 2019, t. 13, s. 208. 


\section{Obraz „wojennej” Warszawy na kartach A Visztula sellője, A Kárpátoktól a Balti-tengerig oraz Varsói hajnal}

Jak wynika z relacji węgierskich autorów, w Warszawie lat pięćdziesiątych (czy też przełomu lat pięćdziesiątych i sześćdziesiątych) dało się jeszcze dostrzec wyraźnie zniszczenia wojenne, a atmosferę miasta tworzyła także w pewnej mierze pamięć o II wojnie światowej. Tę atmosferę dostrzega i przekazuje węgierskiemu czytelnikowi zwłaszcza dziennikarz i pisarz Péter Ruffy, autor reportażu Varsói hajnal; odwiedzając stolicę Polski ma świadomość, jak wiele przeszło to miasto, jak wielu mieszkańców Warszawy padło ofiarą działań wojennych i niemieckiej okupacji, straciło życie podczas walk powstańczych?:

Spośród miliona 300 tysięcy mieszkańców Warszawy zmarło, zniknęło 920 tysięcy. Chodzę po jednym z największych cmentarzy świata. Jakby kości chrupały pod stopami człowieka. Atakują mnie koszmarne obrazy, wizje, prawie słyszę trzask nazistowskich salw. Jakby trzeszczały wszystkie spojenia, płomienie rozgrzewały powietrze. Jest to jedno z miejsc największych ludzkich dramatów ${ }^{10}$.

W wyżej cytowanym fragmencie Ruffy daje wyraz swoim emocjom związanym $\mathrm{z}$ najnowszą historią polskiej stolicy, którą w innym miejscu nazywa nawet - biorąc pod uwagę całość jej burzliwych dziejów - „miastem-męczennikiem"11; te emocje chce także przekazać węgierskiemu czytelnikowi, pokazać mu Warszawę jako miasto-ofiarę czy też miasto-bohatera, uzmysłowić mu, że polska stolica uległa niemal całkowitej zagładzie. Temu właśnie służy patetyczny styl, emfatyczność i hiperboliczność powyższego opisu (jak zresztą i innych części reportażu; warto w tym miejscu zaznaczyć, że patos, emfaza, a także hiperboliczność relacji są cechami charakterystycznymi Varsói hajnal).

Hiperboliczność należy tutaj rozumieć nie tylko ściśle, jako trop retoryczny (czyli na przykład dobór słownictwa w celu wzmocnienia przekazu - w tym przypadku dotyczącego wojny), ale także jako mechanizm dotyczący płaszczyzny samych faktów - polegające na pewnej przesadności ich zniekształcanie czy „ubarwianie”, a także „udramatyzowanie” rzeczywistości w celu osiągnięcia

\footnotetext{
9 Ibidem, s. 212.

${ }^{10}$ P. RufFy, op. cit., s. 58.

${ }^{11}$ Ibidem, s. 59.
} 
jakiegoś określonego efektu (na przykład wstrząśnięcia czytelnikiem, wzruszenia go, uwypuklenia znaczenia jakiegoś faktu itp.; przykłady tak pojmowanej hiperboliczności podaję w dalszej części tekstu).

W przytoczonym wyżej ustępie hiperbolą rozumianą jako trop retoryczny jest nazwanie Warszawy „jednym z największych cmentarzy świata”; Ruffy uzmysławia $\mathrm{w}$ ten sposób czytelnikowi ogrom strat ludzkich poniesionych przez stolicę Polski w okresie wojny, fakt, iż ciała wielu ofiar działań wojennych na zawsze zostały pod gruzami miasta.

Hiperboli pojmowanej jako „udramatyzowanie” rzeczywistości można by się natomiast doszukiwać w opisie emocji, jakie towarzyszyły Ruffyemu podczas zwiedzania Warszawy. Warto skomentować prawdziwość stwierdzenia: „Spośród miliona trzystu tysięcy mieszkańców Warszawy z ma rło, z n i k nęło 920 tysięcy” [podkreśl. M.G.]. Przy założeniu, że przez osoby, które „zniknęły”, można tu rozumieć osoby zaginione ${ }^{12}$ uznane za zmarłe (co sugeruje kontekst), podawana liczba 920 tysięcy ofiar śmiertelnych jest liczbą zawyżoną. Należy dodać, że wyliczenia strat ludzkich Warszawy różnią się od siebie, pozostają w sferze szacunków i nie mogą być uważane za ścisłe ze względu na brak dokładnych danych statystycznych i przyjmowanie różnych kryteriów przy obliczaniu strat ${ }^{13}$. I tak na przykład, według Encyklopedii Warszawy:

ogółem w latach okupacji niemieckiej zginęło ponad 700 tys. mieszkańców Warszawy, w tym ok. 200 tys. ludności napływowej, totalnej zagładzie uległa społeczność żydowska licząca w1939 r. blisko 350 tys. osób; w samym mieście zginęło ok. 400 tys. osób, z czego znaczna część w jawnych i potajemnych egzekucjach; 130 tys. warszawiaków osadzono w więzieniach i obozach, 375 tys. wywieziono do prac niewolniczych, ok. 330 tys. osób wysiedlono, 165 tys. mieszkańców Warszawy dotkniętych zostało kalectwem i trwałymi schorzeniami ${ }^{14}$.

${ }^{12}$ W oryginale: eltünik, co oznacza nie tylko „zniknąć”, ale i „zaginąć” (polskie ekwiwalenty za: Stownik wegiersko-polski, red. J. ReYCHMAN, Warszawa 1968, s. 289).

${ }^{13}$ K. Dunin-Wąsowicz, Warszawa w latach 1939-1945, Warszawa 1984, s. 83; A. GaWrYSZEWSKI, Ludność Warszawy w XX wieku, Warszawa 2009, s. 86.

${ }^{14}$ Encyklopedia Warszawy, red. B. KaCzOrowski, Warszawa 1994, s. 819. W innym miejscu tejże encyklopedii czytamy o tym, że w latach II wojny światowej życie straciło 850 tys. mieszkańców stolicy, wliczając w to około 200 tys. ludności napływowej; spośród stałych mieszkańców Warszawy zginęło zatem 650 tys. osób (Ibidem, s. 443). Na 685 tys. szacuje liczbę ofiar Krzysztof Dunin-Wąsowicz (K. Dunin-WĄSOWICZ, op. cit., s. 83). Według jeszcze innych danych - opublikowanych w 1972 r. wyliczeń Edwarda Strzeleckiego - straty ludnościowe Warszawy w latach II wojny światowej wyniosły 550 tys. osób (za: A. GAWRYSZEWSKI, op. cit., s. 86). 
Podobną liczbę ofiar śmiertelnych podaje także historyk Marek Getter - pisze on, że w latach wojny życie straciło 729 tysięcy warszawiaków ${ }^{15}$. Tak czy inaczej, straty ludzkie Warszawy w okresie wojny były olbrzymie, należały do największych w skali światowej ${ }^{16}$.

Podawaną przez węgierskiego dziennikarza liczbę 920 tysięcy mieszkańców stolicy - ofiar wojny prawdopodobnie należy odczytywać w kontekście powstania warszawskiego: otóż w dalszej części reportażu Ruffy pisze o 220 tysiącach zabitych w okresie powstania warszawskiego, a także o 700 tysiącach osób wypędzonych z miasta - a zatem właśnie o 920 tysiącach osób. Jednak i w tym "powstańczym” kontekście ową liczbę można uznać za zawyżoną. Do wypędzonych w takim razie może się odnosić użyty w cytowanym wyżej urywku czasownik „zniknąć" ${ }^{\prime 7}$; co ciekawe, w dotyczącym powstania fragmencie reportażu Ruffy o ludziach wypędzonych w 1944 r. z Warszawy pisze, iż „zniknęli z szeregu żywych"18 (do tej kwestii powracam w dalszej części artykułu).

Węgierski pisarz w przytoczonym wyżej fragmencie w sposób obrazowy, ale czytelny, odnosi się do burzliwych losów stolicy w okresie II wojny światowej (w tym do ostatecznego zniszczenia miasta i wysiedlenia jego mieszkańców w 1944 r.). Te wojenne dzieje Warszawy dokładniej przedstawia w dalszej części reportażu - i czyni to najpełniej, w sposób najbardziej kompleksowy, ze wszystkich trzech autorów. Dramatowi Warszawy Péter Ruffy nadaje „ludzką twarz" - z emfazą podkreśla heroizm i męczeństwo ludzi - mieszkańców stolicy. Autor Varsói hajnal wspomina obronę miasta we wrześniu 1939 r. („Warszawa stawiała opór do końca, przez trzy tygodnie”19). Jednym z symboli losów stolicy w czasie kampanii wrześniowej jest pożar Zamku Królewskiego, wywołany niemieckim ostrzałem artyleryjskim. W historii Warszawy zapisała się także akcja ratowania Zamku oraz znajdujących się w nim dzieł sztuki ${ }^{20}$.

15 M. GETTER, Straty ludzkie i materialne w powstaniu warszawskim, „Biuletyn Instytutu Pamięci Narodowej" 2004, nr 8/9 (43/44), s. 70.

16 Encyklopedia Warszawy..., s. 443.

17 Vide: przypis nr 12.

18 P. Ruffy, op. cit., s. 62.

19 Ibidem, s. 59. Ruffy myli się, pisząc o trzech tygodniach „oporu” Warszawy. W rzeczywistości walki o stolicę trwały prawie do końca września; Warszawa skapitulowała dopiero 28 września 1939 r. (vide np. Encyklopedia Warszawy..., s. 557).

${ }^{20} \mathrm{Na}$ temat ratowania skarbów Zamku Królewskiego w Warszawie we wrześniu 1939 r. pisał np. Tomasz A. Pruszak - vide: T.A. PrusZAK, Zabezpieczanie i ratowanie dziet sztuki $w$ Warszawie wobec zagrożeń w okresie II wojny światowej, „Almanach Warszawy” 2014, t. 8, s. 191-219. 
Ruffy z charakterystycznym dla siebie patosem przywołuje i te wydarzenia: „W szaleństwie wojny, podczas alarmów lotniczych, kiedy spadały bomby, Polacy uratowali 10000 dzieł sztuki i [ich] fragmentów" - czytamy w Varsói hajnal ${ }^{21}$.

$\mathrm{Na}$ kartach reportażu czytamy ponadto o różnych formach nazistowskiego terroru w Warszawie - między innymi o wywózkach mieszkańców Warszawy do obozów zagłady („Już w pierwszych miesiącach [okupacji] młodych mężczyzn i inteligencję masowo wywożono do obozów zagłady Auschwitz, Majdanek i Dachau"22), zamknięciu uczelni wyższych i szkół, a także (częstych) ulicznych egzekucjach:

24 grudnia 1939 roku, w Wigilię Bożego Narodzenia, naziści rozpoczęli masowe uliczne egzekucje w podbitej Warszawie. Egzekucje odbywały się przez ponad pięć lat. W czasie okupacji rzadko trafiał się dzień, kiedy gdzieś nie grzmiała salwa. Jeden dźwięk, który się nie podobal, jedna uznana za „podejrzaną” twarz pociągały za sobą uliczną egzekucję $e^{23}$.

Wyżej przytoczony fragment, choć niewątpliwie dobrze oddaje dramat mieszkańców stolicy pod niemiecką okupacją, zawiera pewne nieścisłości, które wymagają komentarza. Po pierwsze: pisząc o rozpoczęciu „masowych ulicznych egzekucji” w Wigilię Bożego Narodzenia 1939 r., Ruffy ma zapewne na myśli dokonaną przez okupantów zbrodnię w podwarszawskim wówczas Wawrze ${ }^{24}$, która miała jednak miejsce nie 24, a w nocy z 26 na 27 grudnia. Niemcy rozstrzelali wówczas 106 mężczyzn w wieku 16-70 lat ${ }^{25}$. Był to odwet

21 P. Ruffy, op. cit., s. 59.

22 Ibidem, s. 60. Jest to w części odniesienie do przeprowadzanej na terenie całego Generalnego Gubernatorstwa tzw. akcji AB, wymierzonej przeciwko inteligencji polskiej. W Warszawie trwała ona od maja do jesieni 1940 r.; w tym okresie trwały wielkie lapanki uliczne oraz wysyłano pierwsze transporty do obozów w Sachsenhausen i Auschwitz. Egzekucje wykonywano w Puszczy Kampinoskiej, pod położoną w pobliżu Warszawy wsią Palmiry. Łapanki, transporty zatrzymanych do obozów koncentracyjnych miały miejsce także w późniejszych latach okupacji. Wielkie obławy uliczne, których ofiary wysyłano do obozów, były prowadzone na przykład w okresie wzmożonego terroru, od października 1942 r. do maja 1943 r. Wtedy też, w styczniu i marcu 1943 r., skierowano pierwsze transporty do Majdanka (M.M. DrozDowski, A. SoŁTAN, A. ZAHorski, Historia Warszawy, Warszawa 2017 [wyd. szóste popr. i uzup.], s. 419.

23 P. RufFy, op. cit., s. 59-60.

24 Wawer jest częścią Warszawy dopiero od 1951 r. (Encyklopedia Warszawy..., s. 941).

25 W. Bartoszewski, 1859 dni Warszawy, Kraków 2008 [wydanie trzecie - pierwsze bez cenzury], s. 108. 
(na zasadzie odpowiedzialności zbiorowej) ${ }^{26}$ za zabicie dwóch niemieckich podoficerów w miejscowej restauracji przez zawodowych przestępców znanych policji. Właściciela lokalu Antoniego Bartoszka powieszono na drzwiach restauracji. Wydarzenia w Wawrze wstrząsnęły mieszkańcami nie tylko Warszawy, ale i całego kraju ${ }^{27}$. Po drugie: z tekstu Varsói hajnal ${ }^{28}$ wynika, że uliczne egzekucje były zjawiskiem powszechnym przez cały okres okupacji. Choć jest niezaprzeczalnym faktem, że jawne uliczne egzekucje były jednym z najważniejszych i najokrutniejszych przejawów terroru hitlerowskiego, to jednak zostały zapoczątkowane w późniejszej fazie okupacji (przed ich upowszechnieniem pojmanych Polaków zabijano w miejscach odosobnionych, na przykład w podwarszawskich Palmirach czy wśród ruin zburzonego w 1943 r. getta). Jedną z pierwszych egzekucji jawnych czasu niemieckiej okupacji w Warszawie było powieszenie 50 więźniów Pawiaka w dniu 16 października 1942 r. Systematycznych egzekucji ulicznych dokonywano w szczególnie krwawym okresie terroru od 16 października 1943 r. do 15 lutego 1944 r. W celu zastraszenia mieszkańców Warszawy nazwiska straconych podawano publicznie przez megafony oraz na plakatach ${ }^{29}$. Ostatnie, nacechowane dramatyzmem zdanie cytowanego ustępu dobrze wyraża atmosferę terroru, nieustannego zagrożenia i niepewności panującą wśród ludności Warszawy, a także to, że ofiarami niemieckich represji padały bardzo często przypadkowe osoby ${ }^{30}$.

W czasie wizyt autora Varsói hajnal w Warszawie pamięć o tych krwawych wydarzeniach była żywa wśród mieszkańców stolicy, a formy jej pielęgnowania współtworzyły niejako pejzaż i atmosferę miasta; Ruffy zaznacza to już na początku opisu wojennych losów stolicy naszego kraju:

W różnych punktach Warszawy także dzisiaj płoną znicze. Przed zniczami, jako znak szacunku ze strony żyjących, są zawsze tysiące kwiatów. Niejednokrotnie $\mathrm{w}$ trakcie spaceru moi przyjaciele przystawali na moment, w milczeniu, w zadumie. W tych miejscach, przy murach lub na rogach ulic w czasie niemieckiej okupacji dokonywano egzekucji polskich patriotów, dwóch, dziesięciu lub pięćdziesięciu naraz. W ważne rocznice wokół słupów ogłoszeniowych stawiają drut kolczasty, a za kratą wystawiają dawne nazistowskie bekanntmachung, te krwawe rozkazy

\footnotetext{
${ }^{26}$ M.M. Drozdowski, A. SoŁTan, A. Zahorski, op. cit., s. 419.

27 W. BARTOSZEWSKI, op. cit., s. 108.

28 Vide także kolejny cytowany fragment Varsói hajnal.

29 M.M. Drozdowski, A. SoŁTan, A. Zahorski, op. cit., s. 420.

${ }^{30}$ Vide np. Encyklopedia Warszawy..., s. 446.
} 
dzienne, które swego czasu informowały mieszkańców, kogo stracono na otwartej ulicy i gdzie. Lud Warszawy także dzisiaj ogląda te nazistowskie rozkazy. A widział je już nieraz i prawdopodobnie umie wymienić nazwiska na nich figurujące. Czasami, widząc takie zgromadzenia, myślałem, że już nawet nie czytają listy nazwisk. Tylko stoją przed nią długo, z wilgotnymi oczami, z małymi bukietami w dłoniach, nieruchomo. Patrzą w nicość i nie idą dalej ${ }^{31}$.

Ważnymi momentami w wojennych dziejach Warszawy były dwa antyhitlerowskie zrywy ludności: powstanie w getcie warszawskim (1943) oraz powstanie warszawskie (1944). Jeśli chodzi o pierwsze z nich, to piszą o nim wszyscy trzej autorzy - podobnie jak i o samym getcie, straszliwych warunkach w nim panujących oraz eksterminacji ludności żydowskiej ${ }^{32}$ :

Śródmieście Warszawy o powierzchni dwóch kilometrów kwadratowych ${ }^{33}$ otoczono wysokimi murami; zamknięto tutaj polską ludność religii żydowskiej z Warszawy i okolic. Pół miliona ludzi żyło tutaj ściśnięte [na małej powierzchni] ${ }^{34}$, w straszliwych warunkach. Żydów z getta po kolei deportowano, większość z nich zagazowano w Treblince

- czytamy w Varsói hajnaß35. György Somlyó, autor A Visztula sellöje, nazywa warszawskie getto „miejscem największego ludzkiego męczeństwa”36. Trzeci z autorów, Tibor Pethő, wskazuje z kolei na najbardziej dotkliwe aspekty życia w warszawskim getcie: „Stałym zjawiskiem był głód; epidemie, choroby dziesiątkowały zamkniętych tam ludzi" ${ }^{37}$. Ludność żydowska cierpiała także

31 P. RufFy, op. cit., s. 58-59.

32 Getto warszawskie ma bogatą literaturę przedmiotu. Na uwagę zasługuje monumentalne opracowanie Barbary ENGELKING i Jacka LeOCIAKA pt. Getto warszawskie. Przewodnik po nieistniejacym mieście (I wydanie: Warszawa 2001). Jeśli chodzi o węgierskojęzyczne opracowania, to o powstaniu w getcie warszawskim pisała m.in. zmarła niedawno historyczka Katalin Szokolay, znawczyni polskich dziejów (vide: K. SzOKOLAY, És a varsói gettó felkelt..., Budapest 1983).

33 W rzeczywistości powierzchnia getta wynosiła około $3 \mathrm{~km}^{2}$, aczkolwiek była kilkakrotnie zmniejszana (vide np. Encyklopedia Warszawy..., s. 206-207).

34 Ta informacja także wymaga drobnego sprostowania: maksymalna liczba mieszkańców warszawskiego getta wynosiła (w kwietniu 1941 r.) ok. 450 tys. ludzi (R. SAKOWSKA, Ludzie z dzielnicy zamkniętej, Warszawa 1993 [wyd. 2 popr. i rozsz.], s. 29), choć „w obiegu” jest też właśnie liczba pół miliona osób - vide np. Wybuch powstania w getcie warszawskim. Rozmowa z dr. Andrzejem Żbikowskim, https://muzhp.pl/pl/e/1187/wybuch-powstania-w-getcie-warszawskim (dostęp: 6 I 2021).

35 P. RufFy, op. cit., s. 61.

36 Gy. SOMLYÓ, op. cit., s. 9.

37 T. PETHÖ, op. cit., s. 66. 
z powodu ciasnoty, o której pisze zarówno Ruffy (vide cytowany wyżej urywek reportażu), jak i Pethő („getto, w którym swego czasu stłoczono czterysta pięćdziesiąt tysięcy polskich Żydów”38) oraz Somlyó („faszyści stłoczyli tutaj, w tej najciemniejszej i najbardziej niezdrowej części miasta, Getto") ${ }^{39}$.

Samo powstanie z 1943 r. jest przedstawiane przez autora Varsói hajnal w sposób patetyczny, jako „rozpaczliwa walka przeciwko nazistowskiej światowej potędze”, w której „starcy i dzieci strzelali do nazistowskich czołgów”ł0 Na marginesie warto zaznaczyć, że to drugie stwierdzenie ma w pewnym stopniu charakter hiperboliczny (przy założeniu, że przez hiperboliczność rozumiemy pewne zniekształcanie czy „ubarwianie” faktów). Wzmianka w narracji tej części reportażu o „starcach” i „dzieciach” (a więc osobach z racji swojego wieku uchodzących za najsłabsze i najbardziej bezbronne) ma na celu uwypuklenie dramatu i heroizmu Żydów Warszawy, podejmujących walkę z Niemcami. Do powstania z 1943 r. doprowadzili (poprzez dość dobrze zorganizowaną działalność konspiracyjną) i uczestniczyli w nim głównie ludzie młodzi; można zatem powiedzieć, że było ono zrywem przede wszystkim żydowskiej młodzieży. Warto jeszcze dodać, że w ostatnim okresie istnienia getta na jego terenie żyli przeważnie ludzie nadający się do pracy w niemieckich zakładach, czyli młodzi i silni, głównie mężczyźni w wieku produkcyjnym (im udało się uniknąć wywiezienia do obozu zagłady) ${ }^{41}$. Ogromna większość dzieci i starców, a także osób chorych i niepracujących została wywieziona do Treblinki ${ }^{42}$. Po zakończeniu wielkiej deportacji w getcie pozostało około 30 tys. ludzi zatrudnionych w niemieckich zakładach; oprócz tego na jego terenie znajdowało się jeszcze około 30 tys. osób, które ukryły się przed wywózką do obozu zagłady i pozostały w getcie nielegalnie. A zatem na progu powstania warszawskie getto liczyło łącznie około 60 tys. mieszkańców ${ }^{43}$.

Krótki opis powstania z 1943 r., zawarty na kartach reportażu $A$ Kárpátoktól a Balti-tengerig Tibora Pethő, całkowicie wpisuje się w oficjalną polską

38 Ibidem.

39 GY. SomLYÓ, op. cit., s. 9. Należy zaznaczyć, że słowa węgierskiego pisarza są także krytyką (powtarzaną przez niego zapewne za polskimi źródłami informacji) warunków życia panujących w przedwojennej Dzielnicy Północnej. W czasie wojny Dzielnica Północna, zamieszkała głównie przez ludność żydowską, znalazła się w granicach getta.

40 P. RufFY, op. cit., s. 61.

41 Wybuch powstania w getcie...

42 K. Dunin-WĄSOWICZ, op. cit., s. 298.

43 Ibidem. 
narrację historyczną czy też propagandę okresu lat pięćdziesiątych (i okresu komunizmu w ogóle). Pethő kilka razy pisze o związkach Polskiej Partii Robotniczej i Gwardii Ludowej ze zrywem mieszkańców getta, milczy natomiast o pomocy ze strony Armii Krajowej („Grupy Gwardii Ludowej działające w mieście spieszyły na pomoc powstańcom” - czytamy na przykład w książce ${ }^{44}$; podobnie wspomina tylko o lewicowej Żydowskiej Organizacji Bojowej (węg.: Zsidó Harci Szervezet), pomijając rolę i udział w powstaniu Żydowskiego Związku Wojskowego ${ }^{45}$.

György Somlyó przedstawia czytelnikom powstanie niejako przez pryzmat Pomnika Bohaterów Getta. Ów pomnik odsłonięto w piątą rocznicę powstania, w 1948 r. Za dekorację rzeźbiarską odpowiadał Natan Rapaport - warszawski artysta rzeźbiarz pochodzenia żydowskiego. Za kształt formy architektonicznej odpowiadał Leon Marek Suzin. Bodaj najważniejszymi elementami jedenastometrowego monumentu są dwie kompozycje rzeźbiarskie. Od strony zachodniej znajduje się rzeźba Walka, przestawiająca grupę mężczyzn, kobiet i dzieci; pośrodku wyróżnia się postać przywódcy zrywu z 1943 r., Mordechaja Anielewicza. Ta kompozycja jest symbolicznym przedstawieniem walki powstańców i cierpienia mieszkańców getta. Płaskorzeźba umieszczona od strony wschodniej ukazuje męczeństwo warszawskich Żydów - przedstawia kolumnę pogrążonych w cierpieniu kobiet, dzieci i starców prowadzonych przez Niemców w nieznanym kierunku (nad postaciami Żydów widać żołnierskie nazistowskie hełmy i bagnety). Tytuł tej sceny to Pochód na zagtadę. Ważny i symboliczny jest materiał, z którego wykonano warszawski pomnik. Jest to pochodzący ze Szwecji - z kamieniołomów w Hunnebostrand - labradoryt. Ten sam kamień w 1942 r. zamówił architekt Hitlera Albert Speer jako najlepszy materiał pod przyszłe pomniki zwycięstwa Führera ${ }^{46}$. Somlyó w $A$ Visztula sellóje tak pisze o rzeczonym pomniku:

44 T. PETHÖ, op. cit., s. 66. Więcej na temat powstania w propagandzie PRL-u - vide np. Wybuch powstania $w$ getcie...

${ }^{4} \mathrm{O}$ utrwaleniu w okresie PRL-u pamięci wyłącznie ŻOB-u i pomijaniu roli ŻZW-u, a także prawdopodobnych tego przyczynach, pisał np. historyk i publicysta Maciej Kledzik - vide np. M. KLEDZIK, Zapomniani żotnierze $\dot{Z} Z W$, „Rzeczpospolita”, 18 IV 2008, https://www.rp.pl/ artykul/122686-Zapomniani-zolnierze-ZZW.html (dostęp: 9 I 2021).

46 Pomnik Bohaterów Getta (ul. Zamenhofa), https://sztetl.org.pl/pl/miejscowosci/w/18-warszawa/116-miejsca-martyrologii/52110-pomnik-bohaterow-getta-ul-zamenhofa (dostęp: 6 I 2021); J. TRYBuŚ, Przewodnik po warszawskich blokowiskach, Łódź 2018, s. 65. 
Po stronie nowych domów dzielnicy Muranów ${ }^{47}$, na skraju ogromnego pustego placu, niczym samotny olbrzym, niczym wódz armii niewidzialnych cieni wznosi się szary blok granitu. Bryły granitu o wielkości domu polecił przywieźć do Warszawy Adolf Hitler w celu postawienia „kolumny zwycięstwa”48. Teraz wyrastają z niego potężni, odlani z brązu bohaterowie ${ }^{49}$ powstania w warszawskim Getcie, na czele z promieniejącą postacią Mordechaja Anielewicza, młodzieńca dowodzącego walką. Ale kamienny relief z tyłu pomnika, ledwo wystający z granitu, jest chyba jeszcze bardziej wstrząsający. Przedstawia on już nie walczące, ale pokonane, załamane postaci podczas marszu, i tylko kilka widocznych za ich spuszczonymi głowami hełmów bojowych SS bez twarzy i tułowi oraz sterczących bagnetów bez rąk i bez karabinów pokazuje, dokąd oni zmierzają ${ }^{50}$.

O warszawskim Pomniku Bohaterów Getta piszą także dwaj pozostali węgierscy autorzy: Ruffy podobnie jak Somlyó wspomina o materiale, z którego wykonano monument: „Granitowy budulec pomnika Hitler zamówił niegdyś u szwedzkich przemysłowców, by zbudować zeń łuk triumfalny w pobliżu Bramy Brandenburskiej w Berlinie” ${ }^{1}$ ); Pethő pisze natomiast, że „wstrząsający pomnik Rapaporta głosi bohaterstwo osiemdziesięciu tysięcy ludzi”52.

Wszyscy trzej autorzy wspominają także o ostatniej odsłonie dramatu warszawskich Żydów, jaką był upadek powstania, ostateczna eksterminacja mieszkańców getta i jego doszczętne zniszczenie. I tak na przykład, Somlyó pisze, że dzielnicę żydowską „wraz z dziesiątkami tysięcy ludzi $i^{53}$ zniszczyło doszczętnie faszystowskie barbarzyństwo" ${ }^{44}$; Pethő podkreśla, że warszawskie getto

47 Osiedle Muranów wzniesiono po wojnie w miejscu zburzonego przez Niemców getta.

48 Pozyskanie materiału w rzeczywistości wyglądało inaczej, o czym pisze np. Artur Tanikowski: materiał do kamiennej bazy pomnika Rapaport i Suzin pozyskali w Szwecji. We wskazanym im kamieniołomie znaleźli równo przycięte bloki granitu (labradorytu), nie tak dawno jeszcze przeznaczone na pomnik hitlerowskiego zwycięstwa. Miał go zrealizować nadworny rzeźbiarz Führera Arno Breker. Pomysł sprowadzenia ze Szwecji i użycia do Pomnika Bohaterów Getta kamienia przeznaczonego wcześniej na niemiecki pomnik miał wyjść od działaczy Bundu (A. TANIKOwsKi, Zabytek hańby naszych wrogów, a chwaty naszych umęczonych bohaterów. Urodziny Pomnika Bohaterów Getta, „Cwiszn Pomiędzy. Żydowski kwartalnik o literaturze i sztuce” 2013, nr 1/2, s. 114, 116).

49 Dosł.: postaci.

50 Gy. SOMLYÓ, op. cit., s. 15.

51 P. RUFFY, op. cit., s. 61.

52 T. Pethö, op. cit., s. 67. À propos podawanej przez Pethő liczby bohaterów getta: jak to już zostało powiedziane wyżej, w okresie tuż przed wybuchem powstania, po zakończeniu wielkiej akcji likwidacyjnej na terenie getta zostało około 60 tys. osób.

53 Wyróżnienie kursywą: Gy. Somlyó [M.G.].

54 Gy. SOMLYó, op. cit., s. 9. 
„w kwietniu 1943 r. zniknęło z powierzchni ziemi, w ścisłym tego słowa zna-

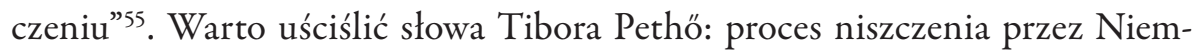
ców getta został zapoczątkowany w kwietniu 1943 r., przebiegał równolegle z dławieniem przez nich powstania ${ }^{56}$. Niszczenie (palenie) domów w getcie było zresztą elementem niemieckiej taktyki walki z żydowskimi bojowcami:

Po pierwszym dniu walki Stroop, który teraz dowodził akcją, zdecydował się zmienić taktykę. Zamiast zaatakowania wprost, co przynosiło zbyt wielkie straty Niemcom, postanowiono demolować i zapalać jeden po drugim poszczególne domy w getcie [podkreśl. M.G.]. (...) Żydów z domów podpalanych wypędzano i albo mordowano na miejscu, albo kierowano do transportów do obozu koncentracyjnego w Majdanku pod Lublinem

- pisze historyk, varsavianista Krzysztof Dunin-Wąsowicz ${ }^{57}$. „Paliliśmy (...) dom po domu. Pozostała tylko kamienno-ceglana pustynia” - tak z kolei niszczenie getta opisywał Kazimierzowi Moczarskiemu kilka lat później w celi więzienia na warszawskim Mokotowie sam Jürgen Stroop ${ }^{58}$.

Za koniec powstania uważa się wysadzenie na rozkaz Stroopa w dniu 16 maja Wielkiej Synagogi, co było też niejako uwieńczeniem procesu burzenia „Żydowskiej Dzielnicy Mieszkaniowej"59. W okresie popowstaniowym niszczono pozostałości warszawskiego getta, zacierano ślady po nim (o czym będzie mowa w dalszej części tekstu).

Wracając do węgierskich reportaży: o zniszczeniu getta czytamy także w Varsói hajnal Pétera Ruffyego:

W zemście [za powstanie - M.G.] Niemcy deportowali całą pozostałą przy życiu ludność getta. Warszawiacy nie słyszeli o ani jednej osobie, która by [stamtąd] powróciła. Po całkowitej deportacji [mieszkańców] budynki - z wyjątkiem kilku - zburzono, ziemię zaorano, a następnie wyrównano buldożerami. W najgęściej

55 T. PETHÖ, op. cit., s. 66.

${ }^{56}$ Reichsführer SS Heinrich Himmler polecił zburzyć warszawskie getto już w lutym tego samego roku. Warto jeszcze dodać, że powstanie w getcie wybuchło jako reakcja na próbę kolejnej deportacji (J. LeOCIAK, Biografie ulic. O żydowskich ulicach Warszawy: od narodzin po Zagtadę, Warszawa 2017, s. 603).

57 K. DUNIN-WĄSOWICZ, op. cit., s. 306.

58 MocZARSKI przywołuje te słowa Stroopa w swoich Rozmowach z katem.

59 Vide np. K. Dunin-WĄSOWICZ, op. cit., s. 307. 
zaludnionej śródmiejskiej dzielnicy Warszawy przetrwał tylko budynek szkolny, gdzie miała siedzibę niszczycielska jednostka SS, poza tym protestancki kościół z przynależną doń plebanią oraz budynek więzienia Pawiak ${ }^{60}$.

Ten fragment reportażu Ruffyego ogólnie bardzo dobrze oddaje tragedię mieszkańców warszawskiego getta, choć pewnego wyjaśnienia i uzupełnienia wymagają dwie podawane przez autora informacje.

Wzmianka o zburzeniu budynków, a zwłaszcza zaoraniu i wyrównaniu buldożerami terenu jest wyraźnym odniesieniem do prac prowadzonych na terenie getta po stłumieniu powstania i ostatecznej eksterminacji ludności żydowskiej. Były to prace polegające na rozbiórce pozostałości budynków, pozyskiwaniu cegieł i złomu żelaznego, przeczesywaniu ruin w poszukiwaniu rzeczy wartościowych czy też odgruzowywaniu i wyrównywaniu terenu, przygotowywaniu go pod planowany park czy też niemieckie osiedle willowe ${ }^{61}$. Niemcy, chcąc zlikwidować pozostałości warszawskiej „dzielnicy zamkniętej” (a zatem niejako wymazać pamięć po niej i po jej żydowskich mieszkańcach), mieli też inny cel, związany z kwestią eksterminowania przez nich ludności żydowskiej: ,jako sprawcy, świadomi swych czynów, zamierzali zatrzeć wszelkie ich ślady"62.

„Porządkowanie” terenu byłego getta opierało się w dużej mierze na niewolniczej pracy więźniów KL Warschau. Był to obóz koncentracyjny założony przez Niemców właśnie na terenie zrujnowanego, „popowstaniowego” getta. Jak zaznacza historyk Bogusław Kopka, działalność obozu „podporządkowana była realizacji ściśle określonego celu - wyburzeniu budynków na terenie byłego getta, niwelacji terenu oraz założeniu parku, po uprzednim wywiezieniu do Rzeszy wszelkich wartościowych rzeczy, majątku ruchomego i nieruchomego"63.

Co ciekawe, Péter Ruffy nie wspomina nic o KL Warschau, mimo iż wiele miejsca poświęca przecież wojennej historii Warszawy, z emfazą opisując dra-

60 P. RuFFY, op. cit., s. 61.

61 Vide: J. LeOciak, op. cit., s. 603-608; B. ChomĄTOwsKa, Stacja Muranów, Wołowiec 2012, s. 93-99; B. KopKA, Konzentrationslager Warschau. Historia i nastepstwa, Warszawa 2007, s. 120; R. JABŁońsKi, Koniec getta $w$ stolicy, „Życie Warszawy”, 14 V 2009, http://www.zw.com.pl/arty$\mathrm{kul} / 362928 . \mathrm{html}$ (dostęp: 15 I 2021).

62 P. Wieczorek, Pamiętamy: KL Warschau (19.07.1943 - 01.08.1944), https://1943.pl/artykul/pamietamy-kl-warschau-19-07-1943-01-08-1944/ (dostęp: 12 I 2021).

63 B. KOPKA, op. cit., s. 120. 
mat stolicy i jej mieszkańców ${ }^{64}$. Być może powodem pominięcia tej - wydawałoby się dość istotnej - informacji jest „komunistyczna” historia miejsca, w którym znajdował się niemiecki obóz. KL Warschau funkcjonował do lata 1944 r. Od stycznia do maja 1945 r. na jego terenie działał obóz NKWD, w którym przetrzymywano między innymi żołnierzy Armii Krajowej i niemieckich jeńców. Następnie obóz przeszedł pod zarząd Ministerstwa Bezpieczeństwa Publicznego; w latach 1945-1949 był obozem dla niemieckich jeńców, a następnie utworzono tam Centralne Więzienie - Ośrodek Pracy w Warszawie, w którym karę odbywały między innymi osoby uznane za wrogów władzy komunistycznej ${ }^{65}$.

Wracając do obrazu warszawskiego getta: warto jeszcze sprostować podawaną w Varsói hajnal informację o ocalałych budynkach. Bodaj najważniejszymi budynkami (jednymi z nielicznych), które przetrwały powstanie $1943 \mathrm{r}$. i zniszczenie getta przez Niemców, były następujące obiekty: więzienie Pawiak, mury Koszar Artylerii Konnej z XVIII w. oraz rzymsko-katolicki kościół pw. św. Augustyna ${ }^{66}$; protestancki (ewangelicko-reformowany) kościól, o którym pisze Ruffy, właściwie znajdował się poza obrębem murów getta, aczkolwiek w jego bezpośrednim sąsiedztwie ${ }^{67}$. Wspomniana przez Pétera Ruffyego szkoła to obecna siedziba Wydziału Psychologii UW przy ul. Stawki. Budynek został postawiony w latach 1936-1938 jako nowoczesny gmach szkolny. W czasie wojny znalazł się na terenie getta. W lecie 1942 r. stał się siedzibą komendy oddziału SS nadzorującego wysiedlenie Żydów. W bezpośrednim sąsiedztwie obiektu znajduje się osławiony Umschlagplatz, skąd odchodziły transporty do Treblinki ${ }^{68}$.

Najważniejszym wydarzeniem w wojennej historii Warszawy, symbolem jej dramatu, było powstanie warszawskie. Jeśli chodzi o omawiane tu relacje węgierskich dziennikarzy i pisarzy, to piszą o nim wyraźnie tylko Péter Ruffy

${ }^{64}$ Pozostali dwaj Węgrzy również nie piszą o KL Warschau.

65 B. KopKA, op. cit., s. 116.

${ }^{66}$ J. ZaCHWATOWICZ, Ochrona i konserwacja zabytków Warszawy, [w:] Kultura Warszawy, red. J. KAZIMIERSKI, Warszawa 1979, s. 345.

${ }^{67}$ Historia zboru warszawskiego, https://reformowani.org.pl/historia (dostęp: 14 I 2021).

68 J. LEOCIAK, op. cit., s. 584-586; vide także: [Historia Wydziatu Psychologii UW] Na Stawkach (lata 1973-1980), http://psych.uw.edu.pl/o-nas/historia/na-stawkach-lata-1973-1980/ (dostęp: 16 I 2021). 
i Tibor Pethő. Przez cały okres PRL-u pamięć o powstaniu podlegała reglamentacji, a na jego ocenę wpływ miały względy polityczne i ideologiczne. Po 1949 r., w związku z umocnieniem się władzy komunistycznej (likwidacją opozycji), zakazano jakiejkolwiek formy otwartego manifestowania pamięci o powstaniu warszawskim. Sama nazwa - jak zaznacza Jacek Z. Sawicki - „najczęściej pojawiała się w kontekście relacji prasowych czy radiowych z kolejnych procesów, wytaczanych żołnierzom AK"69. Rok 1956 zapoczątkował zwalnianie z więzień członków Armii Krajowej i procesy rehabilitacyjne. Zachodzące wówczas przemiany przyniosły (krótkotrwałe) rozluźnienie cenzury, stały się impulsem do bardziej otwartej dyskusji o przeszłości, w tym o powstaniu warszawskim.

Wydawać by się mogło, że w toku gorącej dyskusji runą mury kłamstwa, tymczasem w oficjalnej propagandzie dalej funkcjonował szablon, dzielący środowisko akowskie na cynicznych dowódców i zagubione rzesze żołnierskie. O ile ponownie dopuszczono do głosu tematykę Powstania Warszawskiego, o tyle dalej poddana była ona ścisłej kontroli i służyć miała ostatecznie usankcjonowaniu władzy „ludowej”. Można już było opowiadać o bohaterstwie szeregowych żołnierzy, łączniczek, młodocianych powstańców, ale koniecznie dodając, że byli wykorzystani w niesłusznej politycznie sprawie

- pisze Sawicki ${ }^{70}$.

Oba odniesienia do zrywu mieszkańców Warszawy z 1944 r., zarówno Ruffyego, jak i Pethő, są nacechowane ideologicznie i propagandowo, wpisują się w oficjalną narrację historyczną i polityczną okresu komunizmu (lat pięćdziesiątych oraz przełomu lat pięćdziesiątych i sześćdziesiątych), powielają opisywane przez Jacka Z. Sawickiego schematy i tezy tejże narracji. I tak, autor Varsói hajnal zaznacza, że za wybuch powstania był odpowiedzialny „działający na Zachodzie emigracyjny burżuazyjny polski rząd”71. Wywołanie powstania „przez stronę burżuazyjną” określa słowem esztelenség, którego polskim ekwiwalentem może być zarówno „głupota”, jak i „szaleństwo”72; Ruffy dodaje jednak, że to wcale nie umniejsza „godnego eposu bohaterstwa biorących udział w walkach

${ }^{69}$ J.Z. SAWICKI, Najdtuższa bitwa Peerelu. Powstanie Warszawskie w propagandzie i pamięci, https://wiez.pl/2017/08/01/najdluzsza-bitwa-peerelu-powstanie-warszawskie-w-propagandzie-ipamieci/ (dostęp: 15 I 2021).

70 Ibidem.

71 P. Ruffy, op. cit., s. 61.

72 Polskie ekwiwalenty za: Stownik wegiersko-polski..., s. 317. 
robotników, mieszczan, uczniów, pracowników, kobiet i dzieci, komunistów i bezpartyjnych"73. W tej krytyce jest widoczny wpływ wspominanej wyżej polskiej propagandy, chociaż o powstaniu wypowiadali się krytycznie także członkowie nastawionej antykomunistycznie powojennej polskiej emigracji - między innymi gen. Władysław Anders ${ }^{74}$. Innym przejawem wpisywania się relacji Pétera Ruffyego w nacechowaną propagandowo polską narrację historyczną i polityczną jest choćby podkreślenie w tekście roli komunistów. Faktem jest, że członkowie związanej z Polską Partią Robotniczą Armii Ludowej brali udział w powstaniu ${ }^{75}$, niemniej jednak było ono akcją zbrojną Armii Krajowej, to żołnierze AK stanowili zdecydowaną większość uczestników zrywu, czego Ruffy w żaden sposób nie zaznacza; ani razu nie wymienia też nazwy Armii Krajowej (węg.: Honi Hadsereg) - co rzuca się w oczy zarówno w przytoczonym wyżej fragmencie dotyczącym bohaterstwa uczestników walk, jak i w dalszej części tekstu, w której pisze o „bohaterskiej śmierci 20 tysięcy Polaków, członków warszawskiej [sic!] podziemnej armii"76. Mimo pewnego nacechowania propagandowego przedstawiony w Varsói hajnal obraz powstania, a nawet nie tyle powstania, co samych powstańców, jest pozytywny ${ }^{77}$, utrwala w świadomości czytelnika wizerunek Warszawy jako miasta niezłomnego.

Tibor Pethő o powstaniu warszawskim pisze w kontekście historii Eweliny Rubnickiej (z domu Gabińskiej), po wojnie dyrektorki Drukarni im. Rewolucji Październikowej w Warszawie. Rubnicką poznał osobiście, jej historię usłyszał jednak od „pani Janiny” - ich wspólnej znajomej. Opowieść o Rubnickiej, zajmująca dość obszerny rozdział A Kárpátoktól a Balti-tengerig, jest burzliwą historią wojenną, pełniącą w narracji reportażu rolę historii przykładowej - przez pryzmat losów bohaterki zostaje pokazany wojenny los mieszkańców Warszawy ${ }^{78}$. Historia ta jednak stawia przed badaczem czy też

73 P. Ruffy, op. cit., s. 62. Przez „bezpartyjnych” być może należy rozumieć osoby nienależące do partii komunistycznej.

74 P. Ukielski, Spór o Powstanie Warszawskie, „Biuletyn Instytut Pamięci Narodowej” 2009, nr 8/9 (103/104), s. 121.

75 O udziale Armii Ludowej w powstaniu warszawskim obszernie pisze Antoni Przygoński (Armia Ludowa w Powstaniu Warszawskim 1944, Warszawa 2008, s. 275), który podaje, że w walkach uczestniczyło 1656 żołnierzy tejże formacji, zaznaczając przy tym, że jest to liczba zaniżona.

76 P. RUFFY, op. cit., s. 62.

77 M. GRAD, op. cit., s. 214-215.

78 Ibidem, s. 215. 
(współczesnym) uważnym czytelnikiem kilka znaków zapytania, dotyczących jej wiarygodności; jest bowiem dość bezkrytyczną gloryfikacją związanego z komunistami polskiego podziemia. Wydaje się być historią przynajmniej w części fikcyjną - stworzoną albo odpowiednio „ubogaconą” w celach propagandowych. Istotny może być tu fakt, że wspomniana „pani Janina”, od której węgierski dziennikarz poznał historię Eweliny Rubnickiej, była urzędniczką Komitetu Współpracy Kulturalnej z Zagranicą, opiekującą się nim podczas wizyty w Polsce ${ }^{79}$. Otwarta pozostaje także kwestia, na ile dokładnie historia ta została przekazana na kartach reportażu przez Tibora Pethő; być może węgierski dziennikarz - w celu wywołania odpowiedniego wrażenia u czytelników - nieco ją „urozmaicił” (mam tu na myśli nie tyle fabrykowanie informacji, co ich „koloryzowanie”, dodawanie im dramatyzmu itp.).

Ewelina Rubnicka w latach II wojny światowej jako młoda dziewczyna współpracowała z podziemiem (jak można wywnioskować z tekstu, było ono związane z komunistami), jako sanitariuszka brała udział w powstaniu warszawskim, najpierw wraz z żołnierzami Armii Krajowej, a następnie Armii Ludowej $^{80}$. Obraz powstania warszawskiego wyłaniający się z przekazywanej przez Pethő historii Eweliny Rubnickiej jest - co nie może dziwić - w pełni zgodny z polską oficjalną narracją historyczną i polityczną. Jeśli chodzi o generalia, to przypomina on obraz powstania przedstawiany przez Ruffyego w Varsói hajnal.

Tibor Pethő w sposób bardzo pozytywny pisze o „zwykłych” powstańcach, a przede wszystkim o zaangażowanych w powstanie mieszkańcach Warszawy, o których wypowiada się z prawdziwym podziwem i entuzjazmem. Już na samym początku „powstańczej” części historii Rubnickiej podkreślony zostaje wyraźni heroizm warszawiaków: „Powstanie rozprzestrzeniało się jak pożar, po czterech dniach niemal całe miasto było w ręku powstańców ${ }^{81}$. Kobiety,

${ }^{79} \mathrm{Na}$ tym etapie badań nie jestem w stanie dokonać pełnej oceny przedstawianej na łamach reportażu Tibora Pethő „wojennej” historii Eweliny Rubnickiej i osób z nią związanych. Rozważaniem tych kwestii nie zajmuję się też dokładniej w tym artykule, skupiam się jedynie na ogólnym obrazie powstania warszawskiego, zawartym w przytaczanej przez Pethő historii.

${ }^{80}$ Pethő nazwa tę formację nieprecyzyjnie „Gwardią Ludową” (węg.: Népi Gárda).

${ }^{81}$ Od 1 do 4 sierpnia inicjatywa w walce należała do powstańców, którzy opanowali znaczną część miasta: Śródmieście, Żoliborz, część Mokotowa i Woli. W tym początkowym okresie powstania były też porażki - np. niepowodzenia powstańców na Okęciu czy Pradze (M.M. Drozdowski, A. SOETAN, A. ZAHORSKI, op. cit., s. 434). Maksymalny zasięg powstanie warszawskie miało 4-5 sierpnia 
dzieci, starcy, milion nieuzbrojonych ludzi stawił czoła uzbrojonym po zęby okupantom" - czytamy na kartach reportażu" ${ }^{2}$. To krótkie przedstawienie powstania (a przede wszystkim - jak wskazuje kontekst - jego początków) jest nacechowane patosem, ma także w pewnym stopniu charakter hiperboliczny. $\mathrm{Na}$ początku należy wyjaśnić kwestię liczby ludności zamieszkującej powstańczą Warszawę. Pethő podaje tu liczbę miliona ludzi, którzy „stawili czoła” Niemcom. Na miesiąc przed wybuchem powstania, 1 lipca 1944 r. Warszawa liczyła około 920 tys. mieszkańców: 720 tys. w części lewobrzeżnej i 200 tys. w prawobrzeżnej (na Pradze) ${ }^{83}$; Krzysztof Dunin-Wąsowicz pisze, że liczba mieszkańców stolicy w chwili wybuchu powstania „nie przekraczała (...) w żadnym wypadku miliona ludzi” ${ }^{4}$. Niemniej jednak Niemcom „stawiła czoła” przede wszystkim ludność Warszawy lewobrzeżnej - to lewobrzeżna część stolicy była przecież główną areną trwających 63 dni walk powstańczych ${ }^{85}$; można zatem powiedzieć, że powstanie swoim zasięgiem faktycznie nie objęło wszystkich mieszkańców miasta (owego „miliona nieuzbrojonych ludzi”).

Użyty przez Pethő w oryginale czasownik szembeszáll (przetłumaczony przeze mnie jako „stawić czoła”) oznacza, że ktoś podejmuje walkę ${ }^{86}$. Pamiętając o ofiarnej postawie cywilnej ludności stolicy, o zaangażowaniu wielu warszawiaków na różnych płaszczyznach w sprawę powstania ${ }^{87}$, należy jednak podkreślić, że walczące czynnie (na placu boju) z okupantem zbrojne siły powstania liczyły około 50 tysięcy żołnierzy ${ }^{88}$.

- vide np.: N. DaVIES, Powstanie '44, Kraków 2004, s. 873 [Dodatek 19 - mapa pt. Największy zasięg Powstania, 5 sierpnia 1944].

82 T. PETHÖ, op. cit., s. 48.

83 A. GAWRYSZEWSKI, $o$ p. cit., s. 83.

${ }^{84}$ K. Dunin-WąSOWICZ, op. cit., s. 82.

${ }^{85}$ Prawobrzeżna część Warszawy również wzięła udział w powstaniu, jednak już po czterech dniach dowódcy powstania na Pradze wydali - uzasadnioną zresztą - decyzję o przerwaniu walki. Po 4 sierpnia, w ciągu kilkunastu dni, ok. 550 akowców z Pragi przeprawiło się przez Wisłę do lewobrzeżnej części miasta, by móc kontynuować walkę (K. JóźwIAK, Jak przebiegato powstanie warszawskie na Pradze?, „Rzeczpospolita”, 30 lipca 2019, https://www.rp.pl/Powstanie-Warszawskie/304279882Jak-przebiegalo-powstanie-warszawskie-na-Pradze.html (dostęp: 17 I 2021)).

${ }^{86}$ G. BÁrCZI, L. OrSZÁGH (szerk.), A magyar nyelv értelmező szótára, köt. VI, Budapest 1962, s. 170 [definicja wyrazu szembeszáll].

87 Vide: dalsza część artykułu.

${ }^{88}$ „Przez korpus warszawski przesunęło się około 50000 powstańców, nie licząc sprzysiężonych, którzy nie wzięli udziału w powstaniu" (A. BORKIEWICZ, Powstanie warszawskie 1944. Zarys dziatań natury wojskowej, Warszawa 1969 [wyd. 3], s. 549). 
Wypowiedź Tibora Pethő, mimo że jest w pewnej mierze hiperboliczna ${ }^{89}$, bardzo dobrze pokazuje rzeczywisty heroizm warszawiaków (w tym takżewspominanych kobiet, dzieci, ludzi starszych) i ich aktywny, przybierający rozmaite formy, udział w powstaniu. Jak piszą autorzy Historii Warszawy, ludność stolicy już od samego początku powstania „żywiołowo i spontanicznie wspierała powstańców, zgłaszając się ochotniczo do oddziałów powstańczych, organizując zaplecze, tworząc komitety blokowe, kuchnie, szpitale, oddziały ratownicze i namiastkę administracji” " Na „niezłomnej i ofiarnej” postawie mieszkańców Warszawy opierał się wysiłek zbrojny żołnierzy powstania ${ }^{91}$. Nawet w okresie impasu powstania dzięki niesłabnącemu poparciu ze strony ludności cywilnej powstańcza walka mogła być kontynuowana. Gdyby cywile - posłuchawszy niemieckich rozkazów - poddali się, powstanie mogłoby się szybko załamać ${ }^{92}$. Warto jednak dodać, nie ujmując niczego bohaterskim mieszkańcom stolicy, że - jak możemy przeczytać w Powstaniu'44 Normana Daviesa -

wbrew późniejszym legendom, ludność cywilna nie popierała Powstania z jednakowym entuzjazmem. Można powiedzieć, że większość mieszkańców Warszawy miała poczucie, iż powstańcy walczą o wspólną sprawę. Jednakże znaczący odłam trzymał się z daleka, starając się po prostu przeżyć. I jak zawsze istniały grupy i jednostki stanowiące opozycję. Powstańcza tradycja Polski zawsze przecież budziła głosy krytyki tych, którzy wyśmiewali zapisane w historii dzieje straconych spraw i romantycznych katastrof. W efekcie nastroje wśród cywilnej ludności ulegały znacznym wahaniom, w zależności od sytuacji ${ }^{93}$.

Pisanie o milionie ludzi „stawiających czoła” okupantowi (podejmujących z nim walkę) można zatem uznać za pewną hiperbolę, jako że nie wszyscy warszawiacy włączali się w powstanie. Z drugiej jednak strony to przede wszystkim „Zwykli” mieszkańcy byli największymi ofiarami działań zbrojnych i akcji odwetowych ze strony Niemców ${ }^{94}$. Do wysokich strat wśród ludności cywilnej przyczyniła się w dużej mierze jej ścisła współpraca z prowadzącymi walki

\footnotetext{
89 Vide: dalsza część tekstu.

90 M.M. Drozdowski, A. SoŁTAn, A. Zahorski, op. cit., s. 433.

${ }^{91}$ Encyklopedia Warszawy..., s. 685.

92 N. DAvies, op. cit., s. 401.

${ }^{3}$ Ibidem, s. 394.

94 Vide np. Encyklopedia Warszawy..., s. 685.
} 
powstańcami ${ }^{95}$. Dodatkowo - jak również pisze Davies - „można z pewnością stwierdzić, że nie było w Warszawie żadnej większej grupy osób, które byłyby gotowe pomagać Niemcom w walce z powstańcami"96.

Nieco hiperboliczny charakter może mieć również wymienienie jako „stawiających czoła” niemieckim okupantom nie żołnierzy powstania, a kobiet, dzieci i starców - a zatem osób powszechnie uważanych za słabe i bezbronne; służyć to może mocniejszemu podkreśleniu heroizmu „zwykłych” mieszkańców Warszawy w konfrontacji z Niemcami oraz zwiększeniu dramatyzmu i patosu przekazu. To samo tyczy się wzmianki o tym, że „milion nieuzbrojonych ludzi” musiał zmierzyć się z „uzbrojonymi aż po zęby” niemieckimi okupantami: wojska powstańcze oczywiście były uzbrojone, choć w stopniu dalece niewystarczającym ${ }^{97}$. Cywilna ludność Warszawy była jednak w konfrontacji z Niemcami rzeczywiście całkiem bezbronna.

Historia Eweliny Rubnickiej zawiera jeszcze inne odniesienia do postawy mieszkańców Warszawy w trakcie powstania 1944 r.: „warszawiacy ${ }^{98}$ z ponadludzkim bohaterstwem wytrzymywali tę nierówną walkę"999 - podkreśla heroizm mieszkańców Tibor Pethő. W innym miejscu reportażu czytamy natomiast o tym, że warszawiacy „z cudownym bohaterstwem” rozwiązali problem zaopatrzenia powstania w broń i amunicję, wytwarzając metodami chałupniczymi, „w małych warsztatach”, różne rodzaje niezbędnych środków walki - na przykład granaty ręczne czy zapalające ${ }^{100}$.

Opis walki zbrojnej powstańców warszawskich, a także trudnej sytuacji panującej w trakcie walk po stronie polskiej, jest również nacechowany patosem, emfazą i dramatyzmem:

Ewelinę znów przydzielono do punktu pomocy [medycznej]. Pracowała codziennie po piętnaście-szesnaście godzin, liczba rannych rosła w zastraszającym tempie. (...) Warszawiacy ${ }^{101} \mathrm{z}$ ponadludzkim bohaterstwem wytrzymywali tę nierówną walkę. O każdy dom toczyły się krwawe zmagania. Młodzi chłopcy przy pomocy

\footnotetext{
95 A. BORKIEWICZ, op. cit., s. 549.

${ }_{96}^{6}$ N. Davies, op. cit., s. 394.

${ }^{97} \mathrm{Na}$ temat braków w uzbrojeniu oddziałów powstańczych - vide: np. ibidem, s. 350.

${ }_{98}$ Dosł.: lud.

99 T. PETHÖ, op. cit., s. 51.

${ }^{100}$ Ibidem, s. 48.

101 Vide przypis nr 98.
} 
butelek wypełnionych benzyną niszczyli zza barykad „Tygrysy”. Głowę podniósł głód oraz choroby. Racje żywności były coraz szczuplejsze

- pisze Tibor Pethö ${ }^{102}$.

W tekście są wyraźne odniesienia do Armii Krajowej, nazwa tej formacji także pojawia się na kartach reportażu. Odniesienia te są osadzone zarówno w pozytywnym, jak i negatywnym kontekście. Jeśli chodzi o pierwszy z nich: Rubnicka została wyswobodzona z więzienia gestapo właśnie przez żołnierzy Armii Krajowej ${ }^{103}$, następnie brała udział w powstaniu u boku akowców jako sanitariuszka - jak czytamy w tekście: „Także Ewelinę powstańcy przydzielili do punktu opatrunkowego"104; kiedy została odkomenderowana do dowództwa Armii Ludowej, „ze wzruszeniem pożegnała się z chłopcami, którym mogła zawdzięczać wolność" 105 . Jeśli chodzi o kontekst negatywny: Armia Krajowa, jej dowództwo i członkowie, a także rząd londyński i samo powstanie jako takie jest poddawane surowej ocenie, w której oczywiście dostrzec można odbicie panującej w latach pięćdziesiątych wizji najnowszej historii Polski. I tak na przykład jeden z działaczy komunistycznego podziemia, żołnierz Armii Ludowej - jak wynika z tekstu, wysoko postawiony w jej hierarchii - Juliusz Rubnicki (ps. Tadeusz) ${ }^{106}$, informując Ewelinę (swoją późniejszą żonę) o możliwym wybuchu powstania, mówi jej, że przygotowują się do niego ci, „którzy nie chcą, by Warszawę wyzwoliły oddziały radzieckie oraz żołnierze 1. Armii Wojska Polskiego"107, i którzy „działają na polecenie rządu przebywającego w Anglii, nie zaś stosownie do tutejszej [tj. panującej w Warszawie i Polsce - M.G.] sytuacji i okoliczności"108 (jest to oczywiście odniesienie do dowództwa i członków AK). W innym znów miejscu Rubnicki mówi Ewelinie między innymi to, że

102 T. PETHÖ, op. cit., s. 51.

103 Właśnie w tym kontekście w rozdziale poświęconym losom Rubnickiej pojawia się nazwa Honi Hadsereg, czyli „Armia Krajowa”. Wzmianka o uwolnieniu bohaterki przez akowców rozpoczyna podrozdział poświęcony samemu powstaniu (ibidem, s. 48).

104 Ibidem, s. 49.

105 Ibidem.

106 Częścią wspomnianej wyżej książki A. Przygońskiego pt. Armia Ludowa w Powstaniu Warszawskim 1944 jest słownik żołnierzy Armii Ludowej - uczestników powstania; ani słownik, ani pozostałe części książki nie zawierają żadnej wzmianki o Juliuszu Rubnickim, co jest jednym z wielu znaków zapytania związanych z podawaną przez Pethő historią Eweliny Rubnickiej.

107 T. PETHÖ, op. cit., s. 40.

108 Ibidem. 
wybuch powstania był przedwczesny, rząd na uchodźstwie chciał w ten sposób „zrównoważyć wpływ manifestu lipcowego na polski lud"; stwierdza ponadto, że „Bór-Komorowski i jego ludzie wiodą miasto ku zagładzie”109. Należy zaznaczyć, że te uwagi przynajmniej w części odpowiadają rzeczywistości, jednak w omawianym tekście mają one budować nie konstruktywną krytykę, ale pejoratywny obraz rządu londyńskiego, Armii Krajowej (zwłaszcza jej dowództwa) oraz samego powstania ${ }^{110}$.

Innym przejawem zgodności przytaczanej przez Pethő opowieści z obowiązującą w Polsce w latach powojennych wersją historii jest zaznaczanie pozytywnej roli Armii Ludowej w powstaniu (vide np. „Gwardia Ludowa ${ }^{111}$ - chociaż uważała moment wybuchu powstania za błędny - od początku walczyła na pierwszej linii"112) oraz pisanie o pomocy udzielonej przez Sowietów - w historii Rubnickiej czytamy na przykład o tym, że radzieckie lotnictwo „po pierwszych dniach [powstania]" dokonywało zrzutów amunicji i broni na rzecz powstańców ${ }^{113}$. Jest to przykład motywowanego kwestiami politycznymi i propagandowymi manipulowania faktami. Należy zaznaczyć, że radziecka pomoc rzeczywiście była, ale przyszła zbyt późno, była udzielana dopiero od 13 września, kiedy los powstania był już w zasadzie przesądzony - był to czterdziesty czwarty dzień walk, powstańcy stracili już Wolę, Stare Miasto, Powiśle; swoją drogą pomocy walczącej Warszawie udzieliły nie tylko radzieckie jednostki 1. Frontu Białoruskiego, ale także wchodząca w jego skład 1. Armia Wojska Polskiego. Radziecka pomoc dla powstania miała postać nie tylko zrzutów lotniczych (uzbrojenia, środków medycznych i żywności), ale także osłony powietrznej ze strony lotnictwa bojowego, wsparcia artyleryjskiego, bezpośredniego działania zaczepnego ze strony jednostek idącej razem z Armią Czerwoną 1. Armii Wojska Polskiego (forsowanie Wisły, walki o przyczółki) oraz współdziałania z akcją zrzutową lotnictwa amerykańskiego przez udostępnienie lotnisk radzieckich w okolicach Połtawy. Pomoc była nie tylko spóźniona, ale także nieskuteczna (przykładowo na skutek szczupłości i odosobnienia rejonów powstańczych akcje zrzutowe były efektywne jedynie w minimalnym stopniu $)^{114}$.

\footnotetext{
109 Ibidem, s. 50.

110 M. GRAD, op. cit., s. 216.

111 Vide: przypis nr 80.

112 T. PETHÖ, op. cit., s. 48.

113 Ibidem, s. 48-49.

114 A. PRZYgońsKi, Stalin i Powstanie Warszawskie, Warszawa 1994, s. 175.
} 
Dwa zrywy mieszkańców stolicy, a przede wszystkim planowe zniszczenie Warszawy przez Niemców przeprowadzone po upadku tych powstań, sprawiły, że lewobrzeżna część miasta stała się jedną wielką ruiną ${ }^{115}$. Pierwszym etapem „uśmiercania” miasta była ostateczna eksterminacja ludności żydowskiej i zniszczenie getta w 1943 r. Klęska powstania z 1944 r. przyniosła wysiedlenie pozostałych przy życiu mieszkańców stolicy ${ }^{116}$ - a właściwie lewobrzeżnej jej części - oraz systematyczne, planowe, dokonywane przez specjalne oddziały niemieckie zniszczenie miasta. W wyniku tych działań stolica Polski zmieniła się $\mathrm{w}$ morze opustoszałych ruin ${ }^{117}$. Uzasadnione $\mathrm{w}$ tym kontekście jest zatem użycie przez Pétera Ruffyego w stosunku do popowstaniowej Warszawy określenia „cmentarz” (węg. temető), które choć hiperboliczne, to jednak dobrze oddaje ówczesną sytuację: „Na ten cmentarz, który kiedyś zwano Warszawą, pół roku później, o świcie ${ }^{118} 17$ stycznia 1945 roku wkroczyła niosąca wyzwolenie ${ }^{119}$ armia radziecka i walcząca z nią ramię w ramię 1. Armia Wojska Polskiego" - czytamy w Varsói hajnal ${ }^{120}$.

Chciałbym w tym miejscy przytoczyć dość przejmujący fragment reportażu Varsói hajnal zawierający swego rodzaju bilans zniszczenia stolicy (zniszczenia rozumianego zarówno w sensie materialnym, jak i ludzkim) w czasie powstania warszawskiego i tuż po nim:

Dwadzieścia tysięcy Polaków - członków warszawskiej podziemnej armii - zginęło śmiercią bohaterską. Spośród cywilów życie straciło 200 tysięcy osób, liczba rannych wynosiła 165 tysięcy ludzi. Vernichtungskommando ${ }^{121}$ po kapitulacji [powstania] zmusiło 700 tysięcy warszawiaków do opuszczenia miasta. Nie pozostał po nich ani jeden znak, ani jeden grób, ani jeden zbutwiały drewniany krzyż, ani

115 M. GRAD, op. cit., s. 217.

116 Należy zaznaczyć, że wysiedlenia zaczęły się jeszcze w trakcie powstania warszawskiego.

117 Po upadku powstania i wysiedleniu prawie całej ludności, w lewobrzeżnej Warszawie pozostała tylko niewielka liczba mieszkających na obrzeżach Ochoty i Służewa (ok. 22 tys.) i grupa kilkuset do tysiąca osób ukrywających się w gruzach miasta, których nazwano „robinsonami Warszawy” (A. GAWRYSZEWSKI, op. cit., s. 87).

118 „Życie Warszawy” w numerze („dodatku nadzwyczajnym”) z 17 I 1945 r. informuje, że wojska radzieckie i polskie zajęły lewobrzeżną Warszawę o godz. 10.00 (za: M.M. DrozDowski, A. SołTAN, A. ZAHORSKI, op. cit., s. 445).

119 Dosł.: wyzwoleńcza, wyzwolicielska.

120 P. RUFFY, op. cit., s. 63.

121 Niemiecki oddział specjalny prowadzący działania niszczycielskie w Warszawie po powstaniu. 
jedna linijka tekstu. Zniknęli z szeregu żywych. I w tym opustoszałym mieście na lewym brzegu rzeki, nad prawdziwym grobem 220 tysięcy zmarłych i nad symboliczną mogiłą 700 tysięcy ludzi, na zdrętwiałej ziemi liczącego sobie blisko siedemset lat miasta, które przeżyło tak wiele cierpień ${ }^{122}$, zaczęły szaleć demony ${ }^{123}$.

Część cytowanego wyżej fragmentu Varsói hajnal odnosi się do tragicznych następstw powstania warszawskiego: wypędzenia ludności Warszawy i zniszczenia miasta. Owe „demony, które zaczęły szaleć” w opustoszałej Warszawie to oczywiście niemieccy żołnierze przeprowadzający operację planowego wyburzania i palenia miasta, dokonujący grabieży mienia pozostawionego przez mieszkańców. Opis zniszczenia miasta, a także wypędzenia ludności Warszawy ma charakter hiperboliczny - Ruffy stawia w nim nacisk na pewną poetyckość i dramatyczność, na wywołanie u czytelników emocji. Jeśli chodzi natomiast o fakty, to należy raczej zakwestionować podawaną przez autora liczbę 700 tysięcy warszawiaków zmuszonych do opuszczenia miasta ${ }^{124}$. Nie można też nie skomentować słów, że po wygnańcach „nie pozostał ani jeden znak (itd.)”, że „zniknęli z szeregu żywych”. I w tym przypadku trzeba zakwestionować prawdziwość, czy raczej dosłowność, tych stwierdzeń. Ruffy w sposób symboliczny i metaforyczny wyraża śmierć Warszawy, to, że z tętniącej życiem stolicy kraju stała się ona bezludną, martwą przestrzenią ${ }^{125}$. Powyższe słowa są zatem

${ }^{122}$ Ruffy w przedstawianej na kartach Varsói hajnal historii Warszawy pisze nie tylko o tragedii II wojny światowej, ale także o innych historycznych „kataklizmach”, które nawiedziły stolicę - np. o potopie szwedzkim.

123 Ibidem, s. 62.

124 Trzeba tutaj skonfrontować podawane przez autora liczby z realnym bilansem strat ludzkich Warszawy w okresie powstania, pamiętając o tym, że wyliczenia strat poniesionych przez stolicę w całym okresie wojny (w tym także podczas powstania) pozostają w dużej mierze w sferze szacunków i nie można ich uznać za ścisłe (A. GAWRYSZEWSKI, op. cit., s. 86). Przede wszystkim należy zakwestionować łączną liczbę 920 tys. osób - zabitych podczas powstania i wypędzonych z miasta. Jak pisałem już wyżej, liczba ludności Warszawy w lipcu 1944 r. wynosiła właśnie 920 tys. osób, ale w dotkniętej od sierpnia walkami powstańczymi lewobrzeżnej części miasta mieszkało „tylko” 720 tys. osób (Ibidem, s. 83). Według różnych autorów w powstaniu zginęło od co najmniej 150 tys. do 180 tys., czy nawet do 225 tys. ludności cywilnej (Ibidem, s. 85). Zginęło ok. 16 tys. powstańców; w tej liczbie mieści się 10 tys. poległych oraz 6 tys. zaginionych, których należy traktować jako zabitych (M. GETTER, op.cit., s. 70).Z Warszawy wysiedlono ok. 550 tys. ludzi, choć niemieckie dane mówią o 350 tys.; liczby te dotyczą osób, które miały przejść przez obóz przejściowy oraz rozdzielczy, tzw. Dulag (Durchgangslager) 121 w Pruszkowie (Ibidem, s. 68).

125 M. GRAD, op. cit., s. 220. 
metaforą. Wypędzeni, tracąc swoje miasto, swoje domy rodzinne (nie tylko na skutek samego wysiedlenia, ale i na skutek niszczenia i grabieży Warszawy przez Niemców), stracili swoją przeszłość, swoje korzenie („nie pozostał po nich ani jeden znak (itd.)”), w tym sensie sami stali się martwi („zniknęli z szeregu żywych”). W opustoszałej i zniszczonej przez niemieckie „demony” Warszawie zostało pogrzebane ich dotychczasowe życie; stała się ona zatem ich „symboliczną mogiłą"126.

$\mathrm{Na}$ obecność wojennych ruin w Warszawie nawet kilka, kilkanaście lat po zakończeniu walk zwracają uwagę wszyscy autorzy, a zwłaszcza György Somlyó i Péter Ruffy, zaznaczając, że stopniowo znikają one z pejzażu stolicy.

\section{Zakończenie}

Wszystkie trzy relacje dotyczące losów Warszawy w II wojnie światowej akcentują heroizm stolicy Polski i jej mieszkańców. Autorzy przedstawiają węgierskim czytelnikom wybrane wydarzenia i „motywy” z wojennych dziejów miasta - najwięcej miejsca poświęcając obu powstaniom. W wypowiedziach węgierskich dziennikarzy wyraźny jest podziw dla męstwa mieszkańców Warszawy w okresie II wojny światowej. W moim przekonaniu ów podziw jest szczery; wydaje się, że Tiborowi Pethő, Péterowi Ruffyemu i Györgyowi Somlyó bliskie są sprawy zarówno Warszawy, jak i całej Polski. Relacje trzech węgierskich autorów z pewnością przyczyniły się do lepszego poznania przez Węgrów tego, jak wyglądał czas wojny i okupacji niemieckiej w polskiej stolicy, a przede wszystkim stworzyły w ich oczach obraz Warszawy jako miasto niezłomnego. Należy jednak wyraźnie podkreślić, że kreowany na kartach wymienionych trzech książek obraz stolicy Polski wpisuje się w pełni w ówczesną polską narrację historyczną i polityczną, opierającą się na pokazywaniu heroizmu Polaków; relacje te powielają zatem także oficjalne tezy polskiej propagandy, w niektórych miejscach prezentując wypaczony obraz wojennych dziejów Warszawy.

${ }^{126}$ Losom wypędzonych jest poświęcone m.in. pięciotomowe wydawnictwo pt. Exodus Warszawy. Ludzie i miasto po powstaniu 1944, wybór i oprac. M. Berezowska i in., Warszawa 1992-1995. 


\section{BIBLIOGRAFIA}

\section{Źródła drukowane}

Pethő T., A Kárpátoktól a Balti-tengerig, Budapest 1956.

Ruffy P., Varsói hajnal, Budapest 1961.

Somlyó Gy., A Visztula sellöje. Lengyelországi útinapló, Budapest 1954.

\section{Opracowania}

Bárczi G., Országh L. (szerk.), A magyar nyelv értelmező szótára, köt. VI, Budapest 1962.

Bartoszewski W., 1859 dni Warszawy, Kraków 2008.

Borkiewicz A., Powstanie warszawskie 1944. Zarys dziatań natury wojskowej, Warszawa 1969.

Chomątowska B., Stacja Muranów, Wołowiec 2012.

Davies N., Powstanie'44, Kraków 2004.

Drozdowski M.M., Sołtan A., Zahorski A., Historia Warszawy, Warszawa 2017.

Dunin-Wąsowicz K., Warszawa w latach 1939-1945, Warszawa 1984.

Encyklopedia Warszawy, red. B. Kaczorowski, Warszawa 1994.

Engelking B., Leociak J., Getto warszawskie. Przewodnik po nieistniejacym mieście, Warszawa 2001.

Exodus Warszawy. Ludzie i miasto po powstaniu 1944, wybór i oprac. M. Berezowska i in., Warszawa 1992-1995.

Gawryszewski A., Ludność Warszawy w XX wieku, Warszawa 2009.

Getter M., Straty ludzkie i materialne w powstaniu warszawskim, „Biuletyn Instytutu Pamięci Narodowej” 2004, nr 8/9 (43/44), s. 70.

Grad M., Trzech Wegrów nad Wistą. Warszawa oczami Tibora Pethö, Pétera Ruffy'ego oraz Györgya Somlyó, „Almanach Warszawy” 2019, t. 13, s. 208.

Kopka B., Konzentrationslager Warschau. Historia i nastepstwa, Warszawa 2007.

Leociak J., Biografie ulic. O żydowskich ulicach Warszawy: od narodzin po Zagtade, Warszawa 2017.

Pruszak T.A., Zabezpieczanie i ratowanie dziet sztuki w Warszawie wobec zagrożeń w okresie II wojny światowej, „Almanach Warszawy” 2014, t. 8, s. 191-219.

Przygoński A., Armia Ludowa w Powstaniu Warszawskim 1944, Warszawa 2008. 
Przygoński A., Stalin i Powstanie Warszawskie, Warszawa 1994.

Sakowska R., Ludzie z dzielnicy zamkniętej, [wyd. 2 popr. i rozsz.], Warszawa 1993.

Stownik wegiersko-polski, red. J. Reychman, Warszawa 1968.

Szokolay K., És a varsói gettó felkelt..., Budapest 1983.

Tanikowski A., Zabytek hańby naszych wrogów, a chwaty naszych umęczonych bohaterów. Urodziny Pomnika Bohaterów Getta, „Cwiszn Pomiędzy. Żydowski kwartalnik o literaturze i sztuce" 2013, nr 1/2, s. 114, 116.

Trybuś J., Przewodnik po warszawskich blokowiskach, Łódź 2018.

Ukielski P., Spór o Powstanie Warszawskie, „Biuletyn Instytut Pamięci Narodowej” 2009, nr 8/9 (103/104), s. 121.

Zachwatowicz J., Ochrona i konserwacja zabytków Warszawy, [w:] Kultura Warszawy, red. J. Kazimierski, Warszawa 1979, s. 345.

\section{Netografia}

[Historia Wydziatu Psychologii UW] Na Stawkach (lata 1973-1980), http://psych.uw.edu. pl/o-nas/historia/na-stawkach-lata-1973-1980/ (dostęp: 16 I 2021).

Historia zboru warszawskiego, https://reformowani.org.pl/historia (dostęp: 14 I 2021).

Jabłoński R., Koniec getta w stolicy, „Życie Warszawy”, 14 V 2009, http://www.zw.com.pl/ artykul/362928.html (dostęp: 15 I 2021).

Jóźwiak K., Jak przebiegato powstanie warszawskie na Pradze?, „Rzeczpospolita”, 30 VII 2019, https://www.rp.pl/Powstanie-Warszawskie/304279882-Jak-przebiegalo-powstaniewarszawskie-na-Pradze.html (dostęp: 17 I 2021).

Kledzik M., Zapomniani żotnierze $\dot{Z} Z W$, „Rzeczpospolita”, 18 IV 2008, https://www. rp.pl/artykul/122686-Zapomniani-zolnierze-ZZW.html (dostęp: 9 I 2021).

Pomnik Bohaterów Getta (ul. Zamenhofa), https://sztetl.org.pl/pl/miejscowosci/w/18warszawa/116-miejsca-martyrologii/52110-pomnik-bohaterow-getta-ul-zamenhofa (dostęp: 6 I 2021).

Sawicki J.Z., Najdtuższa bitwa Peerelu. Powstanie Warszawskie w propagandzie i pamięci, https://wiez.pl/2017/08/01/najdluzsza-bitwa-peerelu-powstanie-warszawskie-wpropagandzie-i-pamieci/ (dostęp: 15 I 2021).

Wieczorek P., Pamiętamy: KL Warschau (19.07.1943 - 01.08.1944), https://1943.pl/arty$\mathrm{kul} /$ pamietamy-kl-warschau-19-07-1943-01-08-1944/ (dostęp: 12 I 2021).

Wybuch powstania $w$ getcie warszawskim. Rozmowa $z d r$. Andrzejem Żbikowskim, https://muzhp.pl/pl/e/1187/wybuch-powstania-w-getcie-warszawskim (dostęp: 6 I 2021). 


\title{
Marcin Grad
}

\section{WARSAW'S HISTORY OF II WORLD WAR THROUGH THE EYES OF THREE HUNGARIAN JOURNALISTS AND WRITERS}

\begin{abstract}
Summary. This article is an overview of Warsaw's history during the II World War, presented in the pages of three Hungarian reportages: György Somlyó's A Visztula sellöje. Lengyelországi útinapló (The Vistula's Mermaid. A journal from journey across Poland), Tibor Pethő's A Kárpátoktól a Balti-tengerig (From the Carpathians to the Baltic) and Péter Ruffy's Varsói hajnal (Varsovian dawn). Those books are results of visits of the above-mentioned journalists and writers from Hungary. Somlyó, Pethó and Ruffy were in Poland (including Warsaw) in the 1950s, when the memory of cataclysm of the II World War had been still very vivid, yet in the capital the traces of war were still visible. In the Hungarian authors' reports about history of Warsaw during the years of the II World War, presentation of two uprisings - Warsaw Ghetto Uprising in 1943 and Warsaw Uprising in 1944 (to be precise, it should be noted, that György Somlyó barely writes anything about the latter, which could be politically and ideologically motivated) - occupies an important place. The picture of Varsovian war history presented in the pages of A Visztula sellóje, A Kárpátoktól a Balti-tengerig and Varsói hajnal completely fits polish after-war political and historical narrative, in some parts (e.g. regarding Warsaw Uprising) it is also marked by propaganda. In spite of these "drawbacks", at the time the presented reportages surely contributed to the increasing knowledge of Hungarian readers about the events of II World War in Warsaw and generally in Poland, yet about the after-war rebuild of the country, which, due to the limits concerning volume of texts, will not be included in this article.
\end{abstract}

Keywords: Warsaw, World War II, reportage, Hungarians, Warsaw Ghetto Uprising, Warsaw Uprising 
